\title{
Comparative Analysis on Staffs Professionalism in Faculty of Education and Teacher Training UIN SUSKA Riau Based on Gender
}

\author{
Rian Vebrianto $^{1}$, Z Zarkasih ${ }^{2}$, Nelly Yusro ${ }^{3}$, Oktaf B Kharisma ${ }^{4}$, M Mustakim ${ }^{5}$, MFitriadi ${ }^{6}$, R \\ Riswani $^{7}$, K Kusnadi ${ }^{8}$, Z Zaitun ${ }^{9}$, S Sakilah ${ }^{10}$, Nurhasnawati ${ }^{11}$, Sohiron ${ }^{12}$, Ade Ria Nirmala ${ }^{13}$, \\ Tuti Andriani ${ }^{14}$, Yulia Novita ${ }^{15}$, Khusnal Marzuqo ${ }^{16}$, Richa Dwi Rahmawati ${ }^{17}$, Subhan ${ }^{18}$, Rina \\ Rehayati $^{19}$, Alaniyah Syafaren ${ }^{20}$ \\ Universitas Islam Negeri Sultan Syarif Kasim Riau, Pekanbaru, Indonesia ${ }^{1-12,14-19}$ \\ Universitas Riau, Pekanbaru, Indonesia ${ }^{13,20}$ \\ $\left\{\underline{\text { rian.vebrianto@uin-suska.ac.id }}{ }^{1}\right\}$
}

\begin{abstract}
In an organization, the availability of qualified staff is equivalent to the quality of the human resources and their outputs in the organization. This study aimed to analyze the professionalism of staffs in the Faculty of Education and Teacher Training, UIN SUSKA Riau. This study is essential because all system and processes in the faculty have been done by the staffs to achieve the vision and missions of the university. The study used a mixed method to triangulate data, where the qualitative ones explained the quantitative data. There were 43 respondents participated in the study, comprised of $20(46.50 \%)$ males and $23(53.50 \%)$ females. The instruments were validated in a pilot project, where the instruments' reliability was assessed. The results show that the Cronbach's alpha value reached 0.924 , which means the instruments were excellent to be used in the study. There was no significant difference between the staffs' professionalism based on their gender $(p>0.01)$. We expected that the study results provide a suggestion for future staff recruitment in the faculty to be based on skills and proficiency, not on gender.
\end{abstract}

Keywords: Staffs’ Professionalism, Faculty, Staff Recruitment

\section{Introduction}

Nowadays, people are concerned that there are many cases where government officials, police officer, or other professionals do not show professionalism. The concern even directed to former President Abdurrahman Wahid who was considered incompetent and unprofessional in performing his duties. However, people often use the phrases of profession or professionalism, but they do not understand the meaning of the words. They only see professionalism as an ability to do satisfactory work. In education, there are still many issues of unsatisfactory performance of employees, principals, or educational administrators [1].

In an organization, the availability of qualified staff is equivalent to the quality of the human resources and their outputs in the organization. In a country, the quality of human resources will lead to the welfare of the people. Therefore, improving the welfare of the Indonesian people should be based on developing a quality service and education [2]. 
To meet the demand for professionalism and social change, the quality-based culture is a paradigm that can be used as the basis for establishing learning achievement. It should be implemented in managing the learning process in schools or universities[3].

Professionalism defines the commitment of an individual to improve his professional skills and develop strategies to perform his duty admirably. A professional should manage everything appropriately, particularly aspects related to his profession [4].

The professional development is a process of improving an individual or a group involving various methods, such as reflection, renewing, and improving commitment to achieve better performance. The methods than realized as an effort to improve knowledge, skills, and morals to develop a better idea, design, and practice [5].

The success of a learning process in the university not only influenced by the lectures, but also the administrative staffs. OECD (2005) reported that the human resources of Indonesia would not provide any benefit without the improvement of their quality. Data from ASEAN Productivity Organization (APO) shows that only $4.3 \%$ of 1000 Indonesian labors were skilfull while the Philippines, Malaysia, and Singapore reached 8.3\%, 32.6\%, and 34.7\%, respectively[6].

In the gender issues, women are considered more emotional than men. Some women also have to take care of their families; therefore, they face a tougher challenge to be successful in their career [7]. Hillary (1993) argues that there are cultural expectations of man and woman, where a woman is considered gentle, beautiful, and motherly, while a man is regarded strong, rational, manly, and mighty[8].

Therefore, it is essential to develop an alternative to improve staffs' competence by explaining the importance of professionalism [2], [9], [10]. This study aimed to design and develop a valid problem-solving model that can be implemented to develop the professionalism of staffs in the Faculty of Education and Teacher Training UIN Suska Riau based on gender.

Professionalization is a process to make an agency, organization, and business entity, including the human resources, to be professional. Professionalization centers on improving qualification or skills of a person to achieve the standard of excellence in his occupation. It is a series of professional development conducted by pre-service or in-service training. Hence, professionalization is a lifelong process [11].

Requirements to be a professionals include (1) mastering the job (responsibility), (2) loyal and committed (obedience), (3) having integrity and motivation (personality), (4) hard working (work achievement), (5) visionary (leadership), and (6) proud to his profession (cooperation).In this study, the professionalism of administrative staffs was assessed by their competence in the aspects of work achievement, responsibility, personality, cooperation, obedience, and leadership. These are the essential aspects of behaviors, expertise, or quality of a professional. Competence is the rational behavior to achieve predetermined objectives according to the standard conditions (Lion 2015). Therefore, a professional requires excellent work skills in a particular discipline, and competence is another factor that can be used to assess qualification [12]. It is clear that men and women have the same opportunity to improve themselves professionally.

\section{Method}

The study was conducted in the Faculty of Education and Teacher Training UIN SUSKA Riau from September to November 2017. The research objects were the administrative staffs in the Faculty of Education and Teacher Training UIN SUSKA Riau. 
Data required to analyze factors relating to staffs' preparation, implementation, and professionalism were obtained from an in-depth interview, questionnaires, and observation. The research instruments were interview guideline, questionnaire forms, and observation sheets. This study used the mixed-method, where the quantitative data were explained by the qualitative data with CIPP procedure [13]. The study instruments were validated in the pilot project, where the reliability of the staffs' professionalism instrument had the Cronbach's alpha value of 0.924 , which proved the quality of the instruments

\section{Result and discussion}

\subsection{Profiles of Research Subjects}

The study involved 43 administrative staffs in the Faculty of Education and Teacher Training UIN SUSKA Riau. The data were analyzed descriptively to generate the profiles of research subjects, which are shown in Table 1.

Table 1. Profiles of Research Subjects

\begin{tabular}{llcc}
\hline \multicolumn{1}{c}{ Aspect } & \multicolumn{1}{c}{ Value } & N & Percentage (\%) \\
\hline Gender & Male & 20 & 46.50 \\
Employment status & Female & 23 & 53.50 \\
& Civil servant & 6 & 14.00 \\
& Non-civil servant & 34 & 79.00 \\
Age & Temporary & 3 & 7.00 \\
& $0-25$ & 3 & 7.00 \\
& $26-30$ & 13 & 30.20 \\
Educational background & $31-35$ & 14 & 32.60 \\
& $36-40$ & 9 & 20.90 \\
& $>41$ & 4 & 9.30 \\
Health status & Doctorate & 2 & 4.70 \\
Duration of service & Master & 21 & 48.80 \\
& Bachelor & 13 & 30.20 \\
& Senior high school & 7 & 16.30 \\
& Healthy & 43 & 100.00 \\
& Not healthy & 0 & 0.00 \\
& $0-1$ & 11 & 25.60 \\
& 2 s/d 5 & 8 & 18.60 \\
& 6 s/d 10 & 14 & 32.60 \\
& 11 s/d 15 & 9 & 20.90 \\
& $>15$ & 1 & 2.30 \\
\hline
\end{tabular}

Majority of the administrative staffs were non-civil servant employee, with the percentage reached $79 \%$. There were also six (14\%) staffs who were civil servants and $3(7 \%)$ temporary employees. Most of the research subjects aged $31-35(32.6 \%)$, closely followed by those with the age of $26-30(30.2 \%)$. The next place was staffs aged $36-40$ years $(20.9 \%)$, older than 41 years old $(9.3 \%)$, and lasted less than 25 years old $(7 \%)$. In the educational background, 21 (48.8\%) staffs were masters, $13(30.2 \%)$ were bachelors, seven $(16.3 \%)$ were high school graduates, and two $(4.7 \%)$ were doctors. Even though there were 
more women than men selected as the research subjects, but the slight difference was considered insignificant.

In the health aspects, all subjects were healthy. Meanwhile, $11(25.6 \%$ of the research subjects had worked for less than one year, 8 (18.6\%) for two to five years, $14(32.6 \%)$ for six to ten years, $9(20.9 \%)$ for more than ten years, and one $(2.3 \%)$ for more than 15 years.

The data shows that administrative staffs in the Faculty of Education and Teacher Training UIN SUSKA Riauhad the ideal gender comparison and the potential to develop themselves professionally.

\subsection{Descriptive analysis}

In the pilot project, the reliability of the instruments used in this study was analyzed, and they had the Cronbach's alpha value of 0.924. Chua (2009) states that the minimum reliability value of a quality research instrument is 0.6 , which means that the instruments used in this study were excellent and useful [14]. The reliability results of questionnaire items are displayed in Table 2.

Table 2. Reliability Results of Questionnaire Items

\begin{tabular}{llccl}
\hline NO & \multicolumn{1}{c}{ Question } & N of items & Cronbach's alpha & Instrument quality \\
\hline 1 & Work achievement & 9 & 0.784 & Good \\
2 & Responsibility & 5 & 0.750 & Good \\
3 & Personality & 7 & 0.842 & Excellent \\
4 & Cooperation & 4 & 0.860 & Excellent \\
5 & Leadership & 7 & 0.873 & Excellent \\
6 & Obedience & 5 & 0.777 & Good \\
& Professionalism & 37 & 0.924 & Excellent \\
\hline
\end{tabular}

As shown in Table 2, every variable in the instrument was in the good or excellent categories, which means that the instrument was excellent to assess the staffs' professionalism. The quality of the instrument is essential in ensuring the obtained data are consistent and relevant. The analysis results of the staffs' perception of professionalism are shown in Tables 3 to 8 .

Table 3. Perception of Research Subjects on Professionalism Based on Work Achievement Aspect

\begin{tabular}{clcccc}
\hline \multirow{2}{*}{ No } & Work achievement Aspect & \multicolumn{4}{c}{ Descriptive analysis result } \\
\cline { 3 - 6 } & & N & Min & SD & Assessment \\
\hline 1 & Proficient in his or her work & 43 & 4.28 & 0.504 & Regularly \\
2. & Skilled in his or her work & 43 & 4.26 & 0.492 & Regularly \\
3. & Completing his or her work on schedule & 43 & 4.44 & 0.548 & Regularly \\
4. & Performing the given tasks effectively and & 43 & 4.19 & 0.732 & Regularly \\
& efficiently & 43 & 4.44 & 0.502 & Regularly \\
5 & Mastering his or her field of work & 43 & 4.33 & 0.606 & Regularly \\
6 & Creative & 43 & 4.19 & 0.664 & Regularly \\
7 & Innovative & 43 & 4.42 & 0.587 & Regularly \\
8 & Taking initiative & & & &
\end{tabular}


Table 3 displays that in the aspect of work achievement, the research subjects regularly performed their task professionally $(\min =4.32, \mathrm{sd}=0.58)$. All items of subjects' work achievement had min values in the range of 4.19 to 4.44 with a standard deviation of 0.492 0,732 . The highest assessment was achieved in the aspect of whether the staffs mastered their field of work. Meanwhile, the lowest assessment was obtained in the aspect of performing the given tasks effectively and efficiently.

Table 4. Perception of Research Subjects on Professionalism Based on Responsibility Aspect

\begin{tabular}{|c|c|c|c|c|c|}
\hline \multirow[t]{2}{*}{ No } & \multirow[t]{2}{*}{ Responsibility Aspect } & \multicolumn{4}{|c|}{ Descriptive analysis result } \\
\hline & & $\mathbf{N}$ & Min & SD & Assessment \\
\hline 1 & $\begin{array}{l}\text { Prioritizing the interests of the office rather } \\
\text { than self-interest, others, or groups }\end{array}$ & 43 & 4.16 & 0.61 & Regularly \\
\hline 2. & $\begin{array}{l}\text { Maintaining state property entrusted to him or } \\
\text { her }\end{array}$ & 43 & 4.47 & 0.55 & Regularly \\
\hline 3. & Taking risks of the decisions that are made & 43 & 4.05 & 0.57 & Regularly \\
\hline 4 & Not abusing authority and responsibility & 43 & 4.30 & 0.91 & Regularly \\
\hline 5 & Reporting the work to the superior truthfully & 43 & 4.47 & 0.63 & Regularly \\
\hline \multicolumn{2}{|c|}{ Responsibility } & 43 & 4.29 & 0.66 & Regularly \\
\hline
\end{tabular}

As can be seen in Table 4 , in the aspect of responsibility, the research subjects regularly performed their task professionally $(\mathrm{min}=4.29, \mathrm{sd}=0.66)$. All items of subjects' responsibility had min values in the range of 4.05 to 4.47 with the standard deviation of $0.550-0,914$. The highest assessment was achieved in the aspect of whether the staffs maintained state property entrusted to him or her and reported the work to the superior truthfully. Meanwhile, the lowest assessment was obtained in the aspect of taking risks of the decisions that are made.

Table 5. Perception of Research Subjects on Professionalism Based on the Personality Aspect

\begin{tabular}{llcccc}
\hline \multirow{2}{*}{ No } & Personality Aspect & \multicolumn{4}{c}{ Descriptive analysis result } \\
\cline { 3 - 6 } & & N & Min & SD & Assessment \\
\hline 1 & Performing the given task sincerely & 43 & 4.44 & 0.70 & Regularly \\
2. & Behaving exemplary & 43 & 4.40 & 0.62 & Regularly \\
3. & Knowing his or her ability & 43 & 4.42 & 0.54 & Regularly \\
4. & Dress neatly & 43 & 4.40 & 0.54 & Regularly \\
5 & Reliable & 43 & 4.26 & 0.58 & Regularly \\
6 & Having self-control in various situation and & 43 & 4.19 & 0.62 & Regularly \\
& condition & & & & \\
7 & Fair & 43 & 4.37 & 0.60 & Regularly \\
Personality & 43 & 4,35 & 0.60 & Regularly \\
\hline
\end{tabular}

Table 5 shows that in the aspect of personality, the research subjects regularly performed their task professionally $(\min =4.37, \mathrm{sd}=0.60)$. All items of subjects' personality had min values in the range of 4.19 to 4.42 with the standard deviation of $0.541-0,700$. The highest assessment was achieved in the aspect of whether the staffs performed the given task 
sincerely. Meanwhile, the lowest assessment was obtained in the aspect of having selfcontrol in various situation and condition.

The results show that the administrative staffs regularly perform professionally in aspects of work achievement, responsibility, and personality. However, specific aspect could be improved, such as performing the given tasks effectively and efficiently, taking risks of the decisions that are made, and having self-control in various situation and condition.

Table 6. Perception of research subjects on professionalism based on the cooperation aspect

\begin{tabular}{|c|c|c|c|c|c|}
\hline \multirow[t]{2}{*}{ No } & \multirow[t]{2}{*}{ Cooperation Aspect } & \multicolumn{4}{|c|}{ Descriptive analysis result } \\
\hline & & $\mathbf{N}$ & Min & SD & Assessment \\
\hline 1 & Respecting others' opinions & 43 & 4.47 & 0.51 & Impressive \\
\hline 2. & Being able to work in a team & 43 & 4.53 & 0.51 & Impressive \\
\hline 3. & $\begin{array}{l}\text { Willing to accept a legitimate } \\
\text { decision even if he or she } \\
\text { disagrees }\end{array}$ & 43 & 4.21 & 0.71 & Impressive \\
\hline 4. & $\begin{array}{l}\text { Willing to accept criticism and } \\
\text { suggestions }\end{array}$ & 43 & 4.40 & 0.62 & Impressive \\
\hline Coo & ation & 43 & 4.40 & 0.59 & Impressive \\
\hline
\end{tabular}

As shown in Table 6, in the aspect of cooperation, the research subjects performed their task professionally and impressively $(\min =4.40, \mathrm{sd}=0.59)$. All items of subjects' cooperation had min values in the range of 4.21 to 4.47 with the standard deviation of $0.505-0,709$. The highest assessment was achieved in the aspect of whether the staffs respected others' opinions. Meanwhile, the lowest assessment was obtained in the aspect of willing to accept a legal decision even if he or she disagrees. Therefore, the superior should consider making a decision that is preferred by the majority of the staffs.

Table 7. Perception of Research Subjects on Professionalism Based on the Leadership Aspect

\begin{tabular}{|c|c|c|c|c|c|}
\hline \multirow[t]{2}{*}{ No } & \multirow[t]{2}{*}{ Assessed Aspect } & \multicolumn{4}{|c|}{ Descriptive analysis result } \\
\hline & & $\mathbf{N}$ & Min & SD & Assessment \\
\hline \multicolumn{6}{|c|}{ C. Leadership } \\
\hline 1 & Taking the decision quickly and appropriately & 43 & 4.23 & 0.42 & Impressive \\
\hline 2. & Communicating the work systemically & 43 & 4.28 & 0.54 & Impressive \\
\hline 3. & Determining the work priority appropriately & 43 & 4.23 & 0.52 & Impressive \\
\hline 4 & Acting decisively and impartially & 43 & 4.37 & 0.57 & Impressive \\
\hline 5 & Developing cooperation & 43 & 4.35 & 0.57 & Impressive \\
\hline 6 & $\begin{array}{l}\text { Paying attention and encouraging peer } \\
\text { advancement }\end{array}$ & 43 & 4.28 & 0.50 & Impressive \\
\hline 7 & Having a nurturing attribute & 43 & 4.23 & 0.52 & Impressive \\
\hline \multicolumn{2}{|c|}{ Leadership } & 43 & 4.28 & 0.53 & Impressive \\
\hline
\end{tabular}

Table 7 shows that in the aspect of leadership, the research subjects performed their task professionally and impressively $(\min =4.28, \mathrm{sd}=0.53)$. All items of subjects' leadership had min values in the range of 4.23 to 4.35 with the standard deviation of $0.427-0,578$. The highest assessment was achieved in the aspect of whether the staffs developed cooperation 
with others. Meanwhile, the lowest assessment was obtained in the aspect of taking the decision quickly and appropriately, determining the work priority appropriately, and having a nurturing attribute.

Table 8. Perception of Research Subjects on Professionalism Based on the Obedience Aspect

\begin{tabular}{|c|c|c|c|c|c|}
\hline \multirow[t]{2}{*}{ No } & \multirow[t]{2}{*}{ Assessed Aspect } & \multicolumn{4}{|c|}{ Descriptive analysis result } \\
\hline & & $\mathbf{N}$ & Min & SD & Assessment \\
\hline \multicolumn{6}{|c|}{ D. Obedience } \\
\hline \multirow{2}{*}{$\begin{array}{l}1 . \\
2 .\end{array}$} & Obeying the laws and regulations & 43 & 4.44 & 0.50 & Strongly agree \\
\hline & $\begin{array}{l}\text { Obeying the official orders of the superior } \\
\text { authorities }\end{array}$ & 43 & 4.53 & 0.50 & Strongly agree \\
\hline 3. & Following the working hours & 43 & 4.28 & 0.54 & Strongly agree \\
\hline 4. & Providing excellent service & 43 & 4.42 & 0.58 & Strongly agree \\
\hline \multirow[t]{2}{*}{5.} & Attending routine activities in the university & 43 & 4.14 & 0.56 & Strongly agree \\
\hline & Obedience & 43 & 4.36 & 0.54 & Strongly agree \\
\hline
\end{tabular}

As can be seen in Table 8 , in the aspect of obedience, the research subjects strongly agreed to perform their task professionally $(\min =4.36, \mathrm{sd}=0.54)$. All items of subjects' obedience had min values in the range of 4.14 to 4.55 with the standard deviation of 0.502 0,587. The highest assessment was achieved in the aspect of whether the staffs obeyed the official orders of the superior authorities. Meanwhile, the lowest assessment was obtained in the aspect of attending routine activities at the university.

The results showed that in the aspects of cooperation, leadership, and obedience, there were specific aspect that could be improved, such as willing to accept a legitimate decision even if he or she disagrees, taking the decision quickly and appropriately, determining the work priority appropriately, having a nurturing attribute, and attending routine activities in the university. Improving individual performance could encourage the improvement of all human resources, which is reflected in increased productivity. The perception of work achievement, responsibility, personality, cooperation, leadership, and obedience could bring positive effects on the service quality in the workplace [15].

One common aspect in low-performance staff is the lack of ability to make a decision that will have benefits to others, which is caused by the lack of knowledge and experience. Lowering the expectation is an alternative to address this issue. The subordinates will not be motivated to reach a high level of achievement unless they consider the high expectation from the leader is realistic and achievable [15], [16].

\subsection{Inference Analysis}

Inference analysis was done to answer the research hypothesis, which was:

Ho: There is no significant difference in staffs' professionalism based on gender and duration of service.

The professionalism of staffs in this study was assessed in six aspects, which were work achievement, responsibility, personality, cooperation, leadership, and obedience. However, the inference analysis did not analyze each aspect individually, but all were considered as one whole element in the definition of staffs' professionalism. 
Variance analysis of two-way ANOVA was conducted to compare the staffs' professionalism based on gender. Before the two-way ANOVA run, a normality test was done to ensure all data were standard. Pallant (2005) argues that if the number of sample size is equal to or larger than 30 , then the data can be considered as normally distributed [17]. As the study used 43 samples, the data were considered customarily distributed to be analyzed in the two-way ANOVA test.

The results show that there was no significant difference in staffs' professionalism based on gender ( $\mathrm{p}>0.05)$, as displayed in Table 9 .

Table 9. The two-way ANOVA Results of Staffs' Professionalism Based on Gender and Duration of Service

\begin{tabular}{lcccccc}
\hline Source & Type III Sum of Squares & Df & Mean Square & F & Sig. \\
\hline Gender & 0.320 & 1 & 0.320 & 0.519 & 0.476 \\
$\begin{array}{l}\text { Duration of service } \\
\text { Gender * Duration }\end{array}$ & 3.680 & 4 & 0.920 & 1.492 & 0.227 \\
service & 2.306 & 3 & 0.769 & 1.246 & 0.308 \\
Error & & & & & \\
Total & 20.973 & 34 & 0.617 & & \\
& 5850.819 & 43 & & & \\
\hline
\end{tabular}

As can be seen in Table 9, the significance of gender was $0.476(p>0.01)$, which means that there was no significant difference between gender min value and staffs' professionalism $(\mathrm{F}=0.519 ; \mathrm{df}=1 ; 34 ; \mathrm{p}=0.476)$. Meanwhile, in the aspect of the duration of service, the significance reached $0.227 \quad(\mathrm{p}>0.01)$. It also means that there was no significant difference between min value for the duration of service and staffs' professionalism $(\mathrm{F}=1.492$; $\mathrm{dk}=4 ; 43 ; \mathrm{p}=0.227)$. In the aspect of interaction, the obtained significance value was 0.308 $(p>0.01$ ), which means that there was no significant effect of interaction between gender and duration of service on the professionalism of administrative staffs in the Faculty of Education and Teacher Training, UIN Suska Riau $(\mathrm{F}=1.246 ; \mathrm{df}=3 ; 43 ; \mathrm{p}=0.308)$.

\section{Conclusion}

The results show that the professionalism of the administrative staffs in the Faculty of Education and teacher training was excellent. However, some improvements still could be made. In the aspects of work achievement, responsibility, and personality, aspects that could be improved were performing the given tasks effectively and efficiently, taking risks of the decisions that are made, and having self-control in various situation and condition. Meanwhile, in the aspects of cooperation, leadership, and obedience, aspects that could be improved were the willingness to accept a legal decision even if he or she disagrees, taking the decision quickly and appropriately, determining the work priority appropriately, having a nurturing attribute, and attending routine activities in the university.

The results show that there was no significant difference in staffs' professionalism based on gender. In the topic of satisfaction at work, the opinions were split. Many staffs said that they were satisfied to receive jobs according to their skills. However, a considerable number of staffs also felt dissatisfied because the jobs and responsibilities are often unequal, and they are not involved in the events held by the faculty or university. 


\section{References}

[1] Departemen Pendidikan Nasional, Rancangan Strategies Departemen Pendidikan Nasional Tahun 2010-2014. Jakarta: Departemen Pendidikan Nasional, 2009.

[2] O. S. Tan, Problem-Based Learning Innovation: Using Problem to Power Learning in the 21st Century. Singapore: GALE Cengage Learning, 2003.

[3] E. Linda, "Professionalism, professionality and the development of education professionals," Br. J. Educ. Stud., vol. 56, no. 1, pp. 20-38, 2008.

[4] C. Day and L. Smethem, "The effects of reform: Have teachers really lost their sense of professionalism?," J. Educ. Chang., vol. 10, no. 2-3, pp. 141-157, May 2009.

[5] F. Muhammad, "Model Program Perkembangan Guru Profesionalisme Malaysia," Bil, vol. 2, no. 2, 2015.

[6] Organisation for Economic Co-Operation and Development, The definition and selection of key competencies: Executive summary. Paris, France: Organisation for Economic Co-Operation and Development, 2005.

[7] Hulwati, "Memahami Kesetaraan Gender DalamFiqh: Analisis Teori Evolusi Kontinuitas Fiqh," J. Ilm. Kaji. Gend., vol. 5, no. 1, 2015.

[8] H. M. Lips, Sex and Gender: an Introduction. California: Myfield Publishing Company, 1993.

[9] Kusnandar, Pegawai profesional, implementasi KTSP dan sukses dalam sertifikasi. Jakarta: Rajawali pres, 2010.

[10] Gina Burkhardt et al., En Gauge 21st Century Skills: Literacy in the digital age. Los Angeles, California: North Central Regional Educational Laboratory and the Metiri Group, 2003.

[11] Fachruddin, Pengembangan Profesionalitas Pegawai. Jakarta: Gaung Persada Press, 2009.

[12] J. M. Asmani, Tips Menjadi Pegawai Imperatif, Kreatif dan Inofatif. Yogyakarta: Diva Press, 2010.

[13] J. W. Creswell, Educational Research: planning, conducting and evacuating quantitative dan qualitative research, 4th ed. Boston: Pearson Education,Inc, 2012.

[14] Y. P. Chua, "Statistik Penyelidikan lanjutan." McGraw-Hill, Malaysia, 2009.

[15] W. Tati and Meitiana, "Pengaruh Pengembangan Profesionalisme dan Motivasi Kerja Terhadap Kinerja Guru," JSM (Jurnal Sains Manajemen), vol. 3, no. 2, pp. 112-119, 2014.

[16] Lion Eddy, "Kemampuan Profesionalisme Guru Dalam Pembelajaran Efektif," vol. 2, no. 3. 2015.

[17] J. Pallant, SPSS Survival. A step-by step guide to data analyis using SPSS for Window (version 10). New South Wales, Australia: Allen \& Unwin, 2005. 